\title{
Seroprevalence of HBsAg, Anti-HBs, Anti-HCV and Anti-HIV in Behçet's Disease
}

\section{Behçet Hastalığı'nda HBsAg, Anti-HBs, Anti-HCV ve Anti-HIV Seroprevalansı}

\author{
Desma Eroğlu', @Cahit Yavuz² \\ 'Konya Meram State Hospital, Clinic of Clinical Microbiology and Infectious Diseases, Konya, Turkey \\ ${ }^{2}$ Konya City Hospital, Skin and Venereal Diseases Clinic, Konya, Turkey
}

\begin{abstract}
Introduction: Behçet's disease defined by Turkish dermatologist Hulusi Behçet is an inflammatory disease of unknown etiology and characterized by recurrent oral aphthous ulcers, genital ulcers, uveitis and skin lesions. We aimed to evaluate hepatitis B virus (HBV), hepatitis $C$ virus (HCV) and human immunodeficiency virus (HIV) seroprevalence in Behçet's Disease.

Material and Method: Patients diagnosed with Behçet's disease and followed up by the dermatology outpatient clinic during 12-years period between July 2008 and July 2020 were retrospectively analyzed. Demographic datas and hepatitis B surface antigen ( $\mathrm{HBsAg}$ ) , hepatitis B surface antibody (anti-HBs), hepatitis C antibody (anti$\mathrm{HCV}$ ), human immunodeficiency virus antibody (anti-HIV) results of the patients were recorded.

Results: 359 patients with Behçet's disease were been evaluated in this study. Of these patients, 189 (52.6\%) were female, 170 (47.4\%) were male and the mean age was $37.7 \pm 12.3$ years. HBsAg was positive in $6(1.6 \%)$ patients and Anti-Hbs ab in $82(7.7 \%)$ patients. Anti HIV ab was negative in all patients. Anti-HCV antibodies were found positive in only one case $(0.2 \%)$, and this was confirmed by testing for hepatitis C virus-ribonucleic acid (HCV RNA). HCV RNA was negative in this patient.

Conclusion: When compared with the general population, seropositivity rates were not detected to be high in Behçet's patients. In fact, the immunity rates were found very low. Based on such a finding, it was concluded that screening is required due to increasing immunosupressive treatments today, and individuals should be vaccinated in cases where HBV indicators are negative. In the other studies, investigating the entity, seropositivity rates have been found similar to those in the population. Considering that serological data show regional differences, we thought that, our study will contribute to the literature both national and international grades due to large patient population in our region.
\end{abstract}

Keywords: Behçet's disease, hepatitis B virus, hepatitis C virus, human immunodeficiency virus, seroprevalence

\section{Öz}

Giriş: Behçet hastalığı bir Türk dermatoloğu olan Hulusi Behçet tarafından tanımlanmış; etyolojisi bilinmeyen, tekrarlayan aftöz ülserler, genital ülserler, üveit ve deri lezyonları ile karakterli inflamatuar hastalıktır. Çlışmamızda Behçet hastalarında HBV, HCV ve HIV seroprevalansını değerlendirmeyi amaçladık.

Gereç ve Yöntem: Temmuz 2008 ile Temuuz 2020 tarihleri arasında dermatoloji polikliniğinde takip edilen Behçet hastalarının dosya bilgileri retrospektif olarak analiz edildi. Demografik verileri ile HBsAg, anti-HBs, anti-HCV, Anti-HIV sonuçları kaydedildi.

Sonuçlar: 189'u kadın $(\% 52,6)$ ve 170'i erkek $(\% 47,4)$ olmak üzere

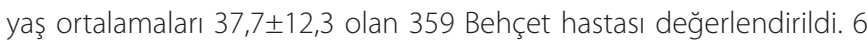
hastada $(\% 1,6)$ HBsAg pozitif olduğu görülürken, 82 hastada $(\% 7,7)$ Anti-Hbs antikorunun pozitif olduğu görüldü. Anti HIV antikorunun tüm hastalarda negatif olduğu görülürken, anti-HCV antikorunun ise sadece 1 hastada pozitif olduğu görüldü $(\% 0,2)$ ve sonucun HCV-RNA ile kontrol edildiği ve negatif olduğu görüldü.

Tartışma: Genel popülasyonla karşılaştıııldığında Behçet hastalarında seropozitiflik oranının yüksek olmadığı görüldü. Esasen immünite oranlarının düşük olduğu görüldü. Elde edilen sonuca göre immünsupresif tedavilerin arttığı günümüzde seroprevalans değerlendirmesinin Behçet hastalarında önemli olduğu düşünüldü. Ayrıca HBV göstergelerinin negatif olduğu hastalarda aşılama düşünülmelidir. Çalışma sonuçlarının genel olarak normal popülasyon ve diğer Behçet hastalığı ile ilgili seroprevalans çalışmalarından farklı olması ülkemizdeki ve bölgemizdeki farklılıklara bağlı olduğu düşünüldü.

Anahtar Kelimeler: Behçet hastalığı, hepatit B virüs, hepatit C virüs, insan immünyetmezlik virüsü 


\section{INTRODUCTION}

Behçet's disease (BD), defined by Hulusi Behçet who is a Turkish dermatologist, is an inflammatory disease of unknown cause characterized by recurrent oral aphthous ulcers, genital ulcers, uveitis and skin lesions. ${ }^{[1,2]} \mathrm{BD}$ is not a persistent inflammatory disease, but a disease consisting of recurrent acute inflammation attacks. ${ }^{[3,4]}$ The disease should be followed up regularly for lifetime. It should be kept in mind that BD is a systemic disease and may affect many organs.

Therefore, it requires a multidisciplinary approach. In general, there is no treatment that cures all symptoms in Behçet's disease. For this reason, treatment must be arranged to the leading symptom. The planned treatment should be started as early as to prevent irreversible organ damages. A wide range of drugs are valid for treatment like colchicine, systemic steroids, azathioprine, cyclophosphamide, dapson, talidomid and the others. ${ }^{[5]}$ Seroprevalence of global and Turkey rates are respectively; for $\mathrm{HBV}$ is $3,5 \%$ and $3,3 \%$, for $\mathrm{HCV}$ is $2,4 \%$ and $2,5 \%$, for HIV is $0,004 \%$ and 0,0012 in population. Pretreatment screening for HBV, HCV and HIV is becoming a current issue due to the risk of reactivate latent infections with the use of immunosuppressive agents. All patients undergoing immunosuppressive drug therapy or monoclonal antibody therapy should be screened, prophylactic antiviral therapy should be initiated when necessary and the patient group not receiving immunosuppressive treatment should be closely monitored. ${ }^{[6-8]}$

Many patients infected with HBV are unaware of the infection or the risk of immunosuppressive treatments. Serological tests should include HBsAg, anti-HBs ab, anti-HCV ab and Anti HIV ab. Further screening is required for suspicious patients. $\mathrm{HBeAg}$, anti-HBe ab and Hepatitis B virus-deoxyribonucleic acid (HBV DNA) must be screened in HBsAg positive cases. [9,10] In addition to these parameters, anti-HCV ab and antiHIV serology should be checked before immunosuppressive treatment. ${ }^{[6]}$

In our study, we aimed to evaluate HBV, HCV and HIV seroprevalence in Behçet's Disease.

\section{MATERIAL AND METHOD}

It's a single center, retrospectively designed study. Local ethic committee approval was obtained. Medical records of dermatology outpatient clinic patients between July 2008 and July 2020 retrospectively scanned with hospital information management system (HBYS). Patients diagnosed with Behçet's disease were retrospectively analyzed. Demographic datas of patients and HBsAg, Anti-HBs ab, Anti-HCV ab, Anti $\mathrm{HIV}$ ab results were recorded. HBsAg, Anti-HBs and Anti HCV serological tests were studied in our laboratory using the chemiluminescence immunoassay technique with Advia Centaur (Siemens) autoanalyzer. All recorded data belonges to different patient and duplicate results are not included. Patients under 18 years of age are excluded.
Results were accepted as positive if $\mathrm{HBsAg} \mathrm{s} / \mathrm{co} \geq 1$, anti$\mathrm{HBs}$ ab $\geq 10 \mathrm{IU} / \mathrm{L}$, anti HCV ab s/co $\geq 1$, anti-HIV ab $\mathrm{s} / \mathrm{co} \geq 1$. Intermediate results were repeated. Patients remaining with intermediate values were not included in the study.

The study was carried out with the permission of Konya Provincial Health Directorate (Date: 04.03.2021, Decision no: E86737044-806.01.03).

\section{RESULTS}

In this study, 359 patients with Behçet's disease were included. All patients had serological tests. Of these patients, 189 (52.6\%) were female, $170(47.4 \%)$ were male and the mean age was $37.7 \pm 12.3$ years (Table 1 ). HBsAg was positive in $6(1.6 \%)$ patients and Anti-Hbs in 82 (7.7\%) patients. Anti HIV was negative in all patients. Anti-HCV antibodies were found positive in only 1 patient $(0.2 \%)$, and this was confirmed by testing for HCV RNA. HCV RNA was negative in this patient (Figure 1).

\begin{tabular}{lc} 
Table 1. Patient characteristics of the study & \\
Patients, $\mathrm{n}$ & 359 \\
Male & 170 \\
Female & 189 \\
Age, mean & 37.7 years $( \pm 12.3)$ \\
\hline
\end{tabular}

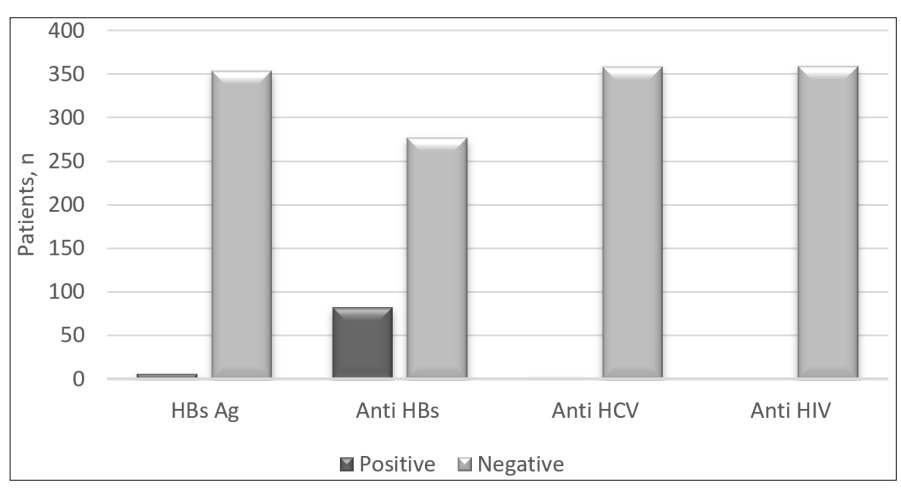

Figure 1. Seroprevalence of patients

\section{DISCUSSION}

$\mathrm{HBsAg}$ was positive in $6(1.6 \%)$ patients and anti-Hbs in 82 (7.7\%) patients, anti HIV was negative in all patients and anti$\mathrm{HCV}$ antibodies were found positive in only 1 patient $(0.2 \%)$ in ourstudy. Duetotheincrease in the use of immunosuppressive drug therapy or monoclonal antibodies in chronic diseases, it has been required to perform serological screening before treatment. ${ }^{[6]}$ Considering the use of immunosuppressive drugs in Behçet's patients, although the seropositivity rates are not found to be high, ${ }^{[11,12]}$ sporadic cases related to hepatitis $B$, hepatitis $C$ or human immunodeficiency virus (HIV) have been reported in Behçet's patients based on the literature. ${ }^{[13-17]}$ However, it should be kept in mind that immunosuppressive treatment may lead to hepatitis B virus reactivation $(\mathrm{HBVr})$ and result in mortality. ${ }^{[6,19,20]}$ In the study performed by Roberto et al. ${ }^{[18]} \mathrm{HBVr}$ was found in a patient 
with Behçet's disease after the use of tumor necrosis factor alpha (TNF-alpha) inhibitors. In the seroprevalence studies conducted in our country, the positivity of HBsAg was found to be $4.22 \%, 10 \%, 12.6 \%, 3.96 \%$ and $4.6 \%$ respectively. ${ }^{[21-25]}$ Farajzadeh et al. ${ }^{[11]}$ reported that HBsAg was detected to be positive in one patient in 48 patients with Behçet's disease. In another study performed in Konya - Turkey, blood donor participants were screened in terms of $\mathrm{HBsAg}$ and the positivity rate was found as $1.53 \% .{ }^{[26]}$ In our study $\mathrm{HbsAg}$ positivity was found to be quite low (1.8\%) in patients with Behçet's disease. Considering that our study was regionally performed, our findings were determined as similar to the positivity rate in the society.

The first community-based investigation of hepatitis $B$ prevalence in Turkey has recently been carried out by Turkish Association for the Study of the Liver (TASL). 5,471 people were screened in this study, the positivity of anti-HBs was found as $32 \% .{ }^{[27]}$ Aksu et al. ${ }^{[28]}$ reported that positivity rates of HBsAg and anti-HBs in patients with Behçet's disease were measured to be 4 and $31 \%$, respectively. Anti-HBs positivity was found to be quite low with a $7.7 \%$ rate in our study. Given the requirement for immunosuppressive treatment, the vaccination has been started to be considered a necessity for patients with Behçet's disease. The fact that such a widely-ranging rate was found in our study suggested that the regional differences. Although hepatitis B vaccination has been accepted to be safe and effective for the general population, the recommendations for hepatitis $B$ vaccination in those with Behçet's disease still remain unclear. ${ }^{[29]}$ If HBV indicators are negative in a patient, the vaccination program should be initiated before administering immunosuppressive treatment, if possible. ${ }^{[6]}$ The response of the vaccine will probably be low in patients administered with immunosuppressive therapy. ${ }^{[30]}$ Vaccines with higher doses or enhanced-efficacy may be required to provide anti-HBs response in patients receiving immunosuppressive treatment. ${ }^{[6]}$ As seen in our study, anti-HBs seropositivity was found to be low in those with Behçet's disease and therefore these patients are considered appropriate to be screened and included in the vaccination program. The prevalence of anti-HCV and anti-HIV $1 / 2$ have been reported as $0.16-5.2 \%$ and $0.007-0.130 \%$ in our country, respectively. ${ }^{[31]}$ There are various studies about seropositivity of HCV in patients with Behçet's disease both supporting relationship or not. ${ }^{[13-15]}$ Farajzadeh et al. ${ }^{[11]}$ reported that there isn't any anti-HCV positivity was found in 48 patients with Behçet's disease. However, in another study, Etem et al. ${ }^{[12]}$ assessed 56 patients with Behçet's disease and stated that anti-HCV positivity was found in one patient while no anti-HIV positivity was detected. As compatible with the finding in the study by Etem et al. ${ }^{[12]}$ anti-HCV positivity was detected only in only one case $(0.8 \%)$ in our study and the reading of HCV RNA test was also negative. Since various HIV infection-related vasculitis syndromes have been encountered recently, it has been suggested that Behçet's disease may also be associated with HIV infection. ${ }^{[16,17]}$ In one HIV case, Behçet's disease was seen to be cured completely with antiretroviral treatment. ${ }^{[32]}$ Although no anti-HIV positivity was detected in our study, such an evidence-based relationship between Behçet's disease and HIV cannot be ignored, and therefore we consider that the patients with Behçet's disease should be screened in terms of anti-HIV positivity.

\section{CONCLUSION}

When compared with the general population, seropositivity rates were not detected to be high in patients with Behçet's disease. In fact, the immunity rates were found very low. Based on such a finding, it was concluded that screening is required due to increasing immunosuppressive treatments today and individuals should be vaccinated in cases where HBV indicators are negative. In most of the studies investigating the entity, seropositivity rates have been found similar to those in the population. Considering that serological data show regional differences, it is clear that our study will contribute to the literature at both national and international levels due to large patient population in our region.

\section{ETHICAL DECLARATIONS}

Ethics Committee Approval: The study was carried out with the permission of Konya Provincial Health Directorate (Date: 04.03.2021, Decision no: E86737044-806.01.03).

Informed Consent: Because the study was designed retrospectively, no written informed consent form was obtained from patients.

Referee Evaluation Process: Externally peer-reviewed.

Conflict of Interest Statement: The authors have no conflicts of interest to declare.

Financial Disclosure: The authors declared that this study has received no financial support.

Author Contributions: All of the authors declare that they have all participated in the design, execution, and analysis of the paper, and that they have approved the final version.

\section{REFERENCES}

1. Alibaz-Oner F, Direskeneli H. Behçet's Disease: Clinical Features. In: Tüzün E. Kürtüncü M. (eds) Neuro-Behçet's Disease. Springer, Cham 2021:55-62.

2. Sakane T, Mitsuhiro C, Suzuki N, Inaba G. Behçet's Disease. N Engl J Med 1999;341:1284-91.

3. Idil A, Gürler A, Boyvat A, et al. The prevalence of Behçet's disease above the age of 10 years. The results of a pilot study conducted at the Park Primary Health Care Center in Ankara, Turkey. Ophthalmic Epidemiol 2002;9:325-31.

4. Alpsoy E, Donmez L, Onder M, et al. Clinical features and natural course of Behçet's disease in 661 cases:a multicentre study. $\mathrm{Br} J$ Dermatol 2007;157:901-6.

5. Alpsoy E. Behçet's disease:Treatment of mucocutaneous lesions. Clin Exp Rheumatol 2005;23:532-9.

6. EASL clinical practice guidelines. Management of chronic hepatitis $B$ virusinfection. J Hepato 2017;57:167-85. 
7. Kaklamani VG, Kaklamanis PG. Treatment of Behçet's diseas-An update. Semin Arthritis Rheum 2001;30:299-312.

8. Law MF, Ho R, Cheung CK, et al. Prevention and management of hepatitis $B$ virus reactivation in patients with hematological malignancies treated with anticancer therapy. World J Gastroenterol 2016;22:6484-500.

9. Lubel JS, Angus PW. Hepatitis B reactivation in patients receiving cytotoxic chemotherapy:diagnosis and management. J Gastroenterol Hepatol 2010;25:864-71.

10. Weinbaum CM, Williams I, Mast EE, et al. Recommendations for identification and public health management of persons with chronic hepatitis B virusinfection. MMWR Recomm Rep 2008;57:1-20

11. Farajzadeh S, Shakibi MR, Darvish Moghaddam S, Rahnama Z. Behçet disease:clinical spectrum and association with hepatitis $B$ and $C$ viruses. Eastern Mediterranean Health J 2005;11:68-72.

12. Etem AA, Etem EÖ, Doğan GT, Yıldırmak ST, Öz I. Seroprevalence of Hepatitis B, C Virus and HIV in Behçet's Disease Living in Usak Region. J Clin Anal Med 2013;4:96-8.

13. Munke H, Stockmann F, Ramadori G. Possible association between Behçet's syndrome and chronic hepatitis C virus infection. New Eng J Med 1995;332:400-1.

14. Hamuryudan V, Sonsuz A, Yurdakul S. More on hepatitis C virus and Behçet's syndrome. New Eng J Med 1995;333:322-3.

15. Ilter N, Şenol E, Gürer MA, Öztaş MO. Behçet's disease and HCV infection. Int J Dermatol 2000;39:396-7.

16. Vega LE, Espinoza LR. Vasculitides in HIV Infection. Curr Rheumatol Rep 2020;22:60.

17. Zhang X, Li H, Li T, Zhang F, Han Y. Distinctive rheumatic manifestations in 98 patients with human immunodeficiency virus infection in China. $J$ Rheumatol 2007;34:1760-4.

18. Pérez-Alvarez R, Díaz-Lagares C, García-Hernández F, et al. Hepatitis B virus (HBV) reactivation in patients receiving tumor necrosis factor (TNF)targeted therapy:analysis of 257 cases. Medicine (Baltimore) 2011;90:35971.

19. Loomba R, Liang TJ. Hepatitis B Reactivation Associated With Immune Suppressive and Biological Modifier Therapies:Current Concepts, Management Strategies, and Future Directions.Gastroenterology 2017;152:1297-309.

20. Karadağ Ö, Kaşifoğlu T, Özer B, et al. Romatolojik hastalarda biyolojik ilaç kullanımı öncesi (viral) hepatit tarama kılavuzu. RAED Derg2015;7:28-32.

21. Asan A, Akbulut A, Sacar S, Turgut H. Tunceli Devlet Hastanesi'ne başvuran kişilerde $\mathrm{HBsAg}$ ve Anti-HCV seroprevalansının değerlendirilmesi. Viral Hepatit Derg 2011;17:52-6.

22. Tunç N, Eraydın H, Çetinkaya E, Oduncu MK, Toy Ş. Siirt Devlet Hastanesi'ne Başvuran Hastalarda HBsAg, Anti-HBs, Anti- HCV ve Anti-HIV Seroprevalansı. Viral Hepatit Derg 2011;17:7-11.

23. Demirpençe Ö, Tezcan SI, Değirmen E, Mert D, Gümüş A, Çelen MK. Batman Devlet Hastanesi'ne başvuran kişilerde Hepatit ve HIV Serolojisinin Sonuçları. Viral Hepatit Derg2012;18:6-10.

24. Innci A, Okay M, Güven D. Artvin Devlet Hastanesi'ne Başvuran Hastalarda HBsAg, Anti-HBs, Anti-HCV ve Anti-HIV Seroprevalansı. Viral Hepatit Derg 2013;19:41-4.

25. Çetinkol Y. Kars Devlet Hastanesi'ne Başvuran Hastalarda HBsAg, AntiHCV ve Anti-HIV Seroprevalansı. Viral Hepatit Derg 2012;18:76-80.

26. Turan H, Şerefhanoğlu K, Kanat-Ünler G, Arslan H. Seroprevalance of $\mathrm{HBsAg}$ and Anti-HCV and Their Correlation to Age and Gender in Blood Donors in the Province of Konya. Klimik Derg 2011;24:36-9.

27. Karaaslan H, Yurdaydin C. Viral hepatitis at the Black Sea region:the problem of viral hepatitis in Turkey revisited. Turk J Gastroenterol 2009;20:1-2.

28. Aksu K, Kabasakal Y, Sayıner A, et al. Prevalences of hepatitis A, B, C and E viruses in Behçet's disease. Rheumatology 1999;38:1279-81.

29. Erkek E, Ayaslioglu E, Erkek AB, Kurtipek GS, Bagci Y, Bagci Y. Response to vaccination against hepatitis $B$ in patients with Behçet's disease. JGastroenterolHepatol2005;20:1508-11.

30. Saco TV, Strauss AT, Ledford DK. Hepatitis B vaccine nonresponders:possible mechanisms and solutions. AnnAllergy Asthma Immunol2018;121:320-27.
31. Demir T. Kırssehir Bölgesindeki Kan Donörlerinin HBsAg, anti-HCV, anti-HIV $1 / 2$ ve Sifiliz Seroprevalansı Yönünden Değerlendirilmesi. Viral Hepatit Derg 2010;16:111-6.

32. Cicalini S, Gigli B, Palmieri F, Boumis E. AIDS and Behçet's disease. Int J STD AIDS 2004; 15:139-40. 